\title{
GROUNDWATER QUALITY ASSESSMENT OF CHILANCHIL ABAY WATERSHED: THE CASE OF BAHIR-DAR CITY WASTE DISPOSAL SITE
}

\author{
Dargie HAILE ${ }^{1}$, Nigus GABBIYE ${ }^{2^{*}}$ \\ ${ }^{1}$ Department of Chemical Engineering, Institute of Technology Woldia University, \\ P.O. Box 400, Kombolcha, Ethiopia \\ ${ }^{2}$ Department of Chemical Engineering, Faculty of Chemical and Food Engineering, \\ Bahir-Dar Institute of Technology Bahir-Dar University, P.O. Box 26, Bahir Dar, Ethiopia
}

Received 29 May 2020; accepted 14 April 2021

\author{
Highlights \\ The study assesses the spatial and temporal variations of groundwater quality. \\ > Total coliform detected were above the permissible limit in all up and downstream. \\ Most of the parameters were registered to be significant temporally over spatially. \\ The result of the study classifies the status of the water shed as marginal. \\ The study classifies the sample points of ground water status by CCMEWQ.
}

\begin{abstract}
Improper dump sites have served many years as an ultimate disposal site for all types of waste; municipal solid waste, industrial sewage and hazardous waste in developing countries such as Ethiopia. Physical, chemical and biological processes interact simultaneously to bring about the overall decomposition of the wastes (chemically laden leachate). If not, deal properly, such kind of dumping site can cause pollution to groundwater (because of Leachates) and surface water (through contaminant transportation by flooding and groundwater movements). Therefore, this study investigates the spatial and temporal variation of groundwater quality within the Chilanchil Abay watershed during dry and wet season due to the waste disposal site of the Bahir Dar city. Water samples were collected from 6 sampling points of groundwater from 30th March to 20th August 2019 by a monthly period. Over 10 water quality parameters such as pH, TDS, Electrical conductivity, Turbidity, Temperature, $\mathrm{DO}, \mathrm{BOD}, \mathrm{COD}, \mathrm{TC}, \mathrm{NO}_{3}{ }^{-}$and $\mathrm{PO}_{4}{ }^{3-}$, were analyzed. Moreover, the overall status of the groundwater quality of the study area was evaluated by the Canadian Water Quality Index. Based on the result of this model the status of the groundwater sample points throughout the study area were raged from 42 to 46.2 (marginal status).
\end{abstract}

Keyword: Bahir-Dar city Waste disposal site, CCMEWQI, Chillan Chile Abay watershed, groundwater, water pollution, seasonal variation.

\section{Introduction}

Water is the most abundant resource on earth, but only $3 \%$ are accessible for human activities while the remaining is present in the ocean as a salt water (Love \& Luchsinger, 2014). It may be available in various forms and quantity, but its use for various purposes is the subject of quality. Of all the environmental concerns that developing countries face, the lack of adequate and clean water remains the most serious problem (Markandya, 2006). Once contaminated, groundwater may forever remain polluted without remedy or treatment. Diseases may spring up through water pollution, especially groundwater contamination, and rapidly spread beyond human expectation because of its flow (Afolayan et al., 2012). Wastes of different types, mostly solid wastes are the major input of dumpsites/landfills. With respect to the hydrological analysis of groundwater, it flows from areas of higher topography towards areas of lower topography, thereby bringing about the examination of the degradable material which forms leachate and contaminate the groundwater of the study area. Unfortunately, groundwater is all too often considered out of sight but it requires great care. Groundwater is not only abstracted for supply or river regulated purposes,

*Corresponding author. E-mail: nigushabtu@gmail.com 
but it also naturally feeds surface -waters through springs and passages into rivers and it is often important in supporting wetlands and their ecosystems. Removal or diversion of groundwater can affect total flow. A reduction in either quality of quantity of the discharging groundwater can significantly influence surface water quality and the attainment of water quality standards. Surface water and groundwater are therefore intimately linked in the water cycle, with many common issues. If groundwater becomes polluted, it is difficult, if not impossible, to rehabilitate. The slow rate of groundwater flow and low microbiological activity, limit any self-purification. Open and improper dumping sites have been served many years as the ultimate disposal site for all types of waste; municipal solid waste, industrial sewage and hazardous waste in developing countries (Nathanson, 2015). Physical, chemical and biological processes interact simultaneously to bring about the overall decomposition of the wastes. One of the by-products of this mechanism is chemically laden leachate and it is a potentially hazardous waste generated from waste disposal sites. If not deal with proper waste management, such kind of dumping site can cause pollution to groundwater (because of Leachates) and surface water (through contaminant transportation by flooding, run-off, wind and ground water movement from the open dump sites). The Bahir Dar city open site is amongst the improper open dump site and located in a place where a number of people are living around. The communities who are living near the disposal site (in a position of downstream and upstream) are using polluted ground and surface water for their day-to-day activities. As a result of this it becomes a great deal or threat to those communities regarding the water quality aspect. Therefore, the focus of this research was to assess and evaluate the water quality in that watershed, especially near this waste disposal site to examine its effect on ground water quality.

\section{Methodology}

\subsection{Descriptions of the study area}

Eriamecharia waste disposal site is $5 \mathrm{~km}$ far away from Bahir Dar city, center on the expressway to Addis Ababa Ethiopia and TIS Abay cascade road. According to the Central Statistics Agency of Ethiopia (CSA 2007 G.C) 3053 females and 3348 males an aggregate of 6401 populaces is found around the dumpsite. Its geological directions are: scope 11.54, longitude 37.38 and height of 1803 meter at and its rise above sea level is 1801 meter. The height and width of this unpredictable shape removal site are $384 \mathrm{~m}$ (by the side of the agrarian place that is known for Eriamecharia) and $174 \mathrm{~m}$ (by the roadside of sebatamit towards Addis Ababa) separately. It has not been furnished either with liners nor leachate assortment framework since it started. Besides, no natural effect appraisal has been done before the determination of this spot to be a waste removal site. Trucks and separate vehicles from various pieces of the city gather and carry the loss to this site and dump in an anarchic manner. The waste is dumped as such without isolation. Then again, the base measure of strong waste which is created from the city and dumped in the site is, private waste $12610 \mathrm{~kg} /$ day, business $4202 \mathrm{~kg}$ / day, specialist co-op $988 \mathrm{~kg} /$ day, civil waste $1044 \mathrm{~kg} /$ day, all out $22774 \mathrm{~kg} /$ day (source: strong waste portrayal and evaluation of the Bahir Dar city report, 2007). At present the base measure of waste dumped at the site is estimated to be $31321 \mathrm{~kg} /$ day. The topographic map of the study area along with the sampling site is presented in Figure 1.

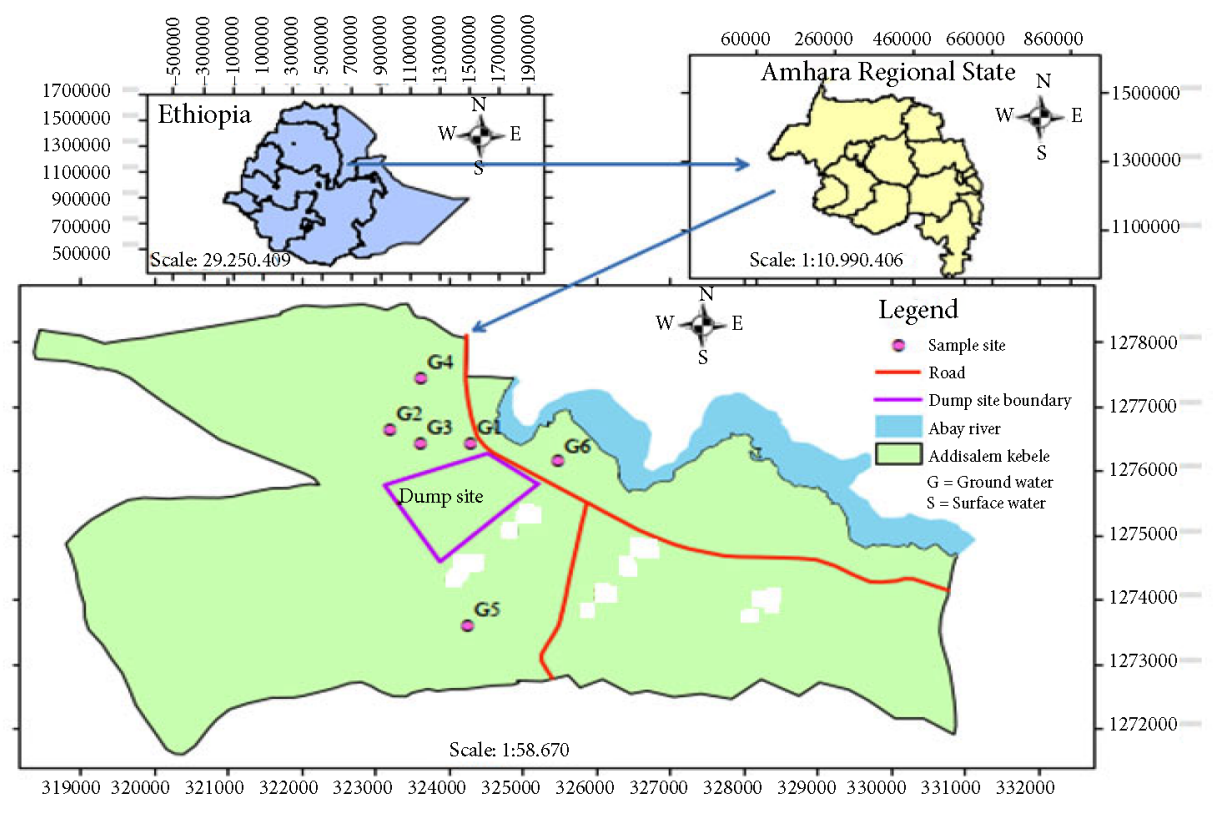

Figure 1. Topographic map of the study area 


\subsection{Sample collection, preservation and laboratory analyses}

Groundwater samples were collected from the selected sample areas near the dumpsite called locally Zebir, to the laboratory for the analysis. Those six sampling points were chosen based on their accessibility, proximity to pollution sources such as communal sites, cottage. Global Positioning System navigator (GPS etrex VISTA HCX) was used to determine the actual positions of the sampling points and referenced to ensure consistency in the sampling points during subsequent sampling periods. The sampling points were carefully selected to include the upstream, and the downstream communities. Taking the sample was started during the dry season from the month of March and continued with a wet season up in the month of August from all the six sample points. Groundwater samples were collected from the depth of 5-12 meter bore holes by using an open water grab sampler 3L capacity prepared with a simple pull - ring that allowed for sampling at various water depths of a borehole for groundwater samples (Hamad, 2018). To assess the water quality, water samples were kept in $1 \mathrm{~L}$ polyethylene plastic bottles cleaned with metal-free soap, rinsed with deionized water and finally soaked by $10 \%$ nitric acid for 24 hours, finally rinsed with ultra-pure water. All water samples were stored in an icebox and delivered on the same day to the laboratory and kept at a constant temperature of $4{ }^{\circ} \mathrm{C}$ (Clesceri et al., 1998). Water quality parameters such as temperature, $\mathrm{pH}$, electrical conductivity, total dissolved solids, turbidity, salinity were measured with handy YSI Pro 30 Multiparameter (model HI 98130 HANNA). Other water quality parameters analyzed include, dissolved oxygen (DO) using HI 98193 dissolved oxygen meter BOD5 using BOD5 incubated in the presence of $\mathrm{NaOH}$, $\mathrm{COD}$ using $\mathrm{COD}$ analysis method in the presence of standard potassium dichromate, sulfuric acid reagent, ferroin indicator and standard ferrous ammonium sulfate titrant and total coil form was done using a membrane filter method. Phosphates $\left(\mathrm{PO}_{4}{ }^{2-}\right)$ and nitrate $\left(\mathrm{NO}_{3}{ }^{-}\right)$were determined using the method of palintest Spectrophotometer (WAGTECH 8000). All the methodologies for laboratory analysis were conducted according to the Standard Methods for the Examination of Water and Wastewater (Clesceri et al., 1998).

\subsection{CCME Water Quality Index procedure}

The CCME WQI model consists of three measures of variance of selected water quality objectives (Scope; Frequency; Amplitude) (Khan et al., 2004). The "Scope $\left(\mathrm{F}_{1}\right)$ " the number of variables not meeting water quality objectives. The "Frequency $\left(\mathrm{F}_{2}\right)$ " the number of times these objectives are not met ("failed tests"). The "Amplitude $\left(\mathrm{F}_{3}\right)$ " represents the amount by which failed tests do not meet their objectives. These three factors combine to produce a unitless value between 0 and 100 that represents the overall water quality. The formulation of the WQI as described in the Canadian Water Quality Index 2001 technical Report is as follows.
The measure for scope $F_{1}$ is calculated as follows:

$$
F_{1}=\left(\frac{\text { Number of failed vaiabbles }}{\text { Total numbers of variables }}\right) \times 100 \text {. }
$$

The measure for frequency $\mathrm{F}_{2}$ is calculated as follows:

$$
\mathrm{F}_{2}=\left(\frac{\text { Number of failed tests }}{\text { Total numbers of tests }}\right) \times 100 \text {. }
$$

The measure for amplitude, $\mathrm{F}_{3}$ is calculated as follows.

The excursion is the number of times by which an individual concentration is greater than (or less than, when the objective is a minimum) the objective. When the test value does not exceed the objective:

$$
\text { Excursion }=100-\left[\frac{\text { objective }}{\text { failed to values }}\right]-1 .
$$

For cases in which the test value exceeds the objective.

$$
\text { Excursion }=100-\left[\frac{\text { failed test value }}{\text { objective }}\right]-1 .
$$

The collective amount by which individual tests are out of compliance is calculated by summing the excursions of individual tests from their objectives and dividing by the total number of tests (both those meeting objectives and those not meeting objectives). This variable, referred to as the normalized sum of excursions (nse) is calculated as:

$$
n s e=\sum_{i=1}^{\infty} \frac{[\text { Excursions }]}{\text { number of tests }} .
$$

$\mathrm{F}_{3}$ is then calculated by an asymptotic function that scales the normalized sum of the excursions from objectives (nse) to yield a range between 0 and 100 .

$$
\mathrm{F}_{3}=\mathrm{F}_{3}=\left(\frac{n s e}{0.01_{n s e}+0.01}\right) \text {. }
$$

The water quality index (CCME WQI) is then calculated as:

$$
\mathrm{CCMEWQI}=100-\left[\frac{\sqrt{F_{1}^{2}+F_{1}^{2}+F_{3}^{2}}}{1.732}\right] .
$$

The divisor 1.732 normalizes the resultant values to a range between 0 and 100, where 0 represents the "worst" water quality and 100 represents the "best" water quality.

\section{Results and discussion}

\subsection{Spatial and temporal variation of groundwater quality}

\subsubsection{Spatial and temporal variation in physical groundwater quality parameters}

The result of spatial and temporal variation of groundwater physical parameters measured in all six sampling points throughout the study time are presented in Table 1.

Total dissolved solid (TDS): The total dissolved solids are an indication of the degree of dissolved substances 
Table 1. Seasonal and temporal variation in physical quality parameters of groundwater

\begin{tabular}{|c|c|c|c|c|c|c|c|c|}
\hline \multirow{2}{*}{$\begin{array}{c}\text { Sampling } \\
\text { sites (SS) }\end{array}$} & \multicolumn{2}{|c|}{$\begin{array}{c}\text { E.C } \\
(\mu \mathrm{S} / \mathrm{m})\end{array}$} & \multicolumn{2}{c|}{ TDS (mg/L) } & \multicolumn{2}{c|}{ Turbidity (NTU) } & \multicolumn{2}{c|}{ Temperature $\left({ }^{\circ} \mathrm{C}\right)$} \\
\cline { 2 - 10 } & Dry season & Wet season & Dry season & Wet season & Dry season & Wet season & Dry Season & Wet season \\
\hline \multirow{2}{*}{ SS1 } & 2037 & 842.33 & 1343.67 & 585.83 & 6.78 & 24.71 & 26.4 & 21.87 \\
& \pm 34.1 & \pm 32.5 & \pm 32.72 & \pm 30.09 & \pm 0.705 & \pm 4.39 & \pm 0.36 & \pm 1.76 \\
\hline \multirow{2}{*}{ SS2 } & 2183.33 & 804.67 & 1294.33 & 560.5 & 6.98 & 27.12 & 24.37 & 21.63 \\
& \pm 176.29 & \pm 16.80 & \pm 6.35 & \pm 44.21 & \pm 0.60 & \pm 1.40 & \pm 3.88 & \pm 2.03 \\
\hline \multirow{2}{*}{ SS3 } & 1939.33 & 869.667 & 1443.33 & 717.67 & 7.32 & 18.94 & 26.7 & 20.97 \\
& \pm 36.295 & \pm 71.93 & \pm 36.94 & \pm 31.501 & \pm 0.43 & \pm 0.55 & \pm 0.56 & \pm 2.59 \\
\hline \multirow{2}{*}{ SS4 } & 2211 & 805.667 & 1427.83 & 617.33 & 7.83 & 22.12 & 25.3 & 23.23 \\
& \pm 62.65 & \pm 56.37 & \pm 26.71 & \pm 69.17 & \pm 0.38 & \pm 5.63 & \pm 2.022 & \pm 0.61 \\
\hline \multirow{2}{*}{ SS5 } & 2271 & 866.67 & 1488 & 843.67 & 13.85 & 32.33 & 28.73 & 22.3 \\
& \pm 24.02 & \pm 37.541 & \pm 12.12 & \pm 89.07 & \pm 3.35 & \pm 3.512 & \pm 1.36 & \pm 2.04 \\
\hline \multirow{2}{*}{ SS6 } & 2220 & 901.67 & 1456 & 755.67 & 12.4 & 31.09 & 27.4 & 23.5033 \\
& \pm 20.66 & \pm 114.18 & \pm 38.31 & \pm 110.74 & \pm 4.82 & \pm 2.87 & \pm 1.42 & \pm 0.54 \\
\hline
\end{tabular}

such as metal ions in the water sample. In this study, the amount of dissolved solid in the ground water samples were ranged from $1294.33 \pm 6.35$ to $1488 \pm 12.12 \mathrm{mg} / \mathrm{L}$ with a mean value of $1408.86 \pm 25.52 \mathrm{mg} / \mathrm{L}$ during the dry season while in a wet season it ranges from $560.5 \pm 44.21$ to $843.67 \pm 89.07 \mathrm{mg} / \mathrm{L}$ with a mean value of $680.11 \pm 62.46 \mathrm{mg} / \mathrm{L}$ (Figure 2, Table 1). The findings of the study indicated that the measured mean values of total dissolved solid during the dry season $(1408.86 \pm 25.52 \mathrm{mg} / \mathrm{L})$ and wet season $(680.11 \pm 62.47 \mathrm{mg} / \mathrm{L})$ were within the WHO's permissible limit $(500-1500 \mathrm{mg} / \mathrm{L})$. But on the base of seasonal variation all values of total dissolved solid during the dry season were higher than the values of the wet season (Figure 2, Table 1). This could be due to the higher temperatures observed during the dry season which facilitated dissolution, ion exchange capacity, desorption and weathering processes. Also, during the dry season borehole water evaporated and ionic concentrations increased. The significance of this temporal variation was supported by the statistical result of one-way ANOVA at 95\% confidence. On The base of spatial variation in both dry and wet season the maximum values of total dissolved solid were observed at $\mathrm{SS}_{5}$ and $\mathrm{SS}_{6}$ whereas the minimum value for dry and wet season recorded at $\mathrm{SS}_{2}$ (Figure 2, Table 1). This was due to the location of those sample points $\left(\mathrm{SS}_{5}\right.$ and $\left.\mathrm{SS}_{6}\right)$ were below the waste

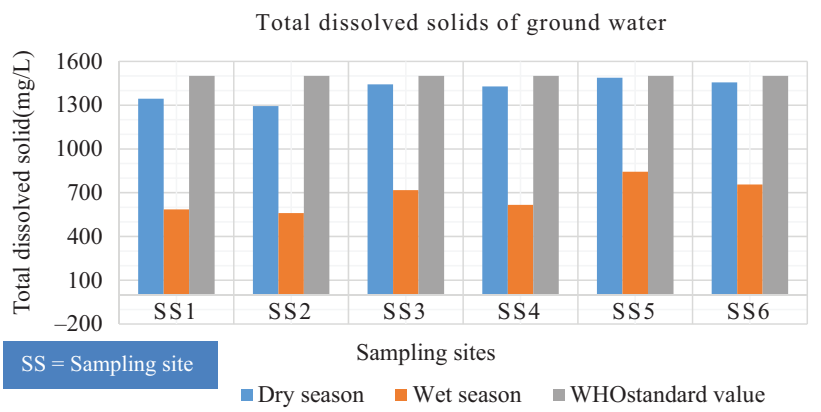

Figure 2. Seasonal variation in total dissolved solid of ground water quality in the study area disposal site which is susceptible to more agricultural runoff and discharged municipal waste flow freely from the dump site while for $\mathrm{SS}_{2}$ above the dump site.

Temperature: The temperature of ground water samples analyzed have a mean temperature value of $26.54 \pm$ $1.58^{\circ} \mathrm{C}$ during the dry season with the highest temperature value of $28.73 \pm 1.36^{\circ} \mathrm{C}$ at SS5. The mean temperature during the wet season was $22.25 \pm 1.59^{\circ} \mathrm{C}$, with the highest value of $23.5033 \pm 0.54{ }^{\circ} \mathrm{Cat} \mathrm{SS}_{5}$ and $\mathrm{SS}_{6}$ (Table 1). From Table 1, one can see that the mean temperature during the dry season was higher than wet season due to the prevailing atmospheric conditions. A higher number of sunshine hours would naturally imply lower relative humidity, a temperature increases of water bodies due to conduction and convection processes by the earth crust. This shows that the temperature of ground water is lower in the wet season than in the dry season. WHO permissible limit stipulates that water for drinking and domestic purposes should have a temperature not exceeding $30-40{ }^{\circ} \mathrm{C}$. Therefore, temperature values recorded for ground water in the study area were within the WHO permissible limit. In most cases temperature changes affect $\mathrm{pH}$, electrical conductivity, sorption processes, complexation, speciation, precipitation, redox reactions, flow rate, ion exchange capacity, solubility of gases and/or other compounds, just to mention but a few. Also, increase in temperature decreases the amount of dissolved oxygen, accelerates nitrification and oxidation of ammonia to nitrates and leading to oxygen deficient water environment. This increases toxicity of pesticides and heavy metals in drinking water. Temperature increase in drinking water leads to a less palatable water taste. Generally, the ANOVA result shows that all the physical properties of ground water quality discussed above were observed to be significantly $(\mathrm{p}<0.05)$ affected by the season. This means the difference regarding season was real but the difference regarding the occurrence of sample site was due to chance(not significant).

Electrical conductivity: Conductivity in groundwater is affected by the geology of the area through which the 
water flows. In this study, the values of electrical conductivity at the six samples of groundwater during dry season ranged from $1939.33 \pm 36.295$ to $2271 \pm 24.02 \mu \mathrm{S} / \mathrm{cm}$ (Figure 3, Table 1) with a mean value of $2143.61 \pm 58.999 \mu \mathrm{S} /$ $\mathrm{cm}$ while in a wet season it varies from $804.67 \pm 16.80$ to $901.667 \pm 114.18 \mu \mathrm{S} / \mathrm{cm}$ with a mean value of $848.44 \pm 54.88 \mu \mathrm{S} / \mathrm{cm}$. The results indicate that the mean values of electrical conductivity for the dry season were higher than the electrical conductivity of the wet season (Figure 3, Table 1). It appears that the values for the dry season exceeds WHO'S standard limit of $1000 \mu \mathrm{S} / \mathrm{cm}$ for drinkable water. This could be due to water evaporates during the dry season and concentration of ions increases hence electrical conductivity increases (the increase in electrical conductivity was due to evaporation of water in under groundwater channels which increased the concentrations of dissolved salts or conducting substances in the borehole water systems). The findings of high-value E.C in a dry season during the study period was similar with the study of (Nsengimana et al., 2012) who have done the assessment of heavy metals in the groundwater wells in the vicinity of Nyanza municipal Solid waste in Kigali CityRwanda and found out the higher value of E.C during the dry season. From the data of dry season, the maximum values were obtained at $\mathrm{SS}_{5}, \mathrm{SS}_{6}$ andSS 4 respectively with a minimum value at $\mathrm{SS}_{3}$ while in a wet season maximum values were recorded orderly at $\mathrm{SS}_{6}, \mathrm{SS}_{3}$ andSS $\mathrm{S}_{5}$ with a minimum value at $\mathrm{SS}_{2}$ (Figure 3, Table 1). These differences in all values of the dry and wet season were due to the location of the sample points from the waste disposal site and other sources of pollution. Generally, Electrical conductivity values provide a useful indicator for spatial and/ or temporal changes in abstraction, salt water intrusion; recharge mechanism, etc. leading to different groundwater qualities in wet and dry seasons.

Turbidity: The measurement of turbidity reflects the transparency in water. It is caused by the substances present in water in suspension. In natural waters it is caused by clay, silt, organic matter, phytoplankton and

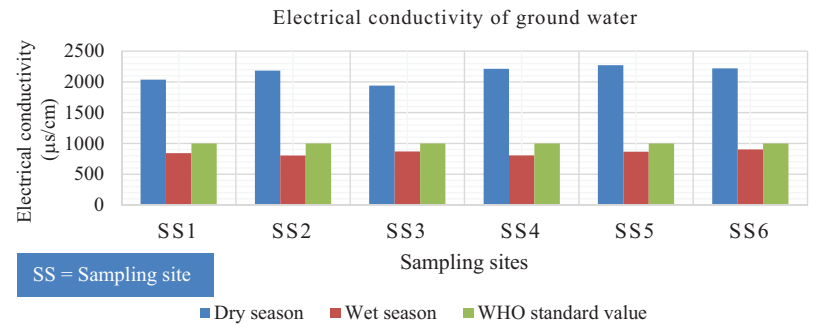

Figure 3. Seasonal variation in Electrical conductivity of groundwater quality in the study area

other microscopic organisms. Mean turbidity values recorded gave an overview of the variations in groundwater quality during wet and dry seasons. In the dry season, the value of turbidity at all six samples of groundwater were ranged between $6.78 \pm 0.705$ to $13.85 \pm 3.35 \mathrm{NTU}$ with a mean value of $7.25 \pm 0.56$ NTU while in the wet season from $18.94 \pm 0.55$ to $32.33 \pm 3.512$ NTU with a mean 26.0517 \pm 3.056 NTU (Figure 4, Table 1). As one can see in Figure 4, the mean values of turbidity recorded in the wet season $(26.0517 \pm 3.056 \mathrm{NTU})$ were higher than WHO permissible limits of 5-25 NTU as well as from the mean value of dry season $(7.25 \pm 0.56 \mathrm{NTU})$. This may have been due to the coagulation of dissolved substances in the boreholes, particles from weathering activities in the underground waterways and surface runoff from agricultural fields around the groundwater sources, dissolved clay and mud materials into the groundwater through infiltration. This means during a rainfall, particles from the waste disposal site and surrounding land are washed into the water sample points and leaching into groundwater making the water a muddy brown color, indicating water that has higher turbidity values. Also, during the rainy season, water velocities are faster and water volumes are higher, which can more easily stir up and suspend material from the stream bed, causing higher turbidities. The reason for the dry season to be lower was because of the reduction in runoff material, precipitates, suspended solids and colored dissolved substances which contributed to the turbidity

Table 2. Seasonal and temporal variation in chemical properties of ground water

\begin{tabular}{|c|c|c|c|c|c|c|c|c|}
\hline \multirow{2}{*}{$\begin{array}{c}\text { Sampling } \\
\text { sites (SS)| }\end{array}$} & \multicolumn{2}{|c|}{$\mathrm{pH}$} & \multicolumn{2}{c|}{ DO (mg/L) } & \multicolumn{2}{c|}{ BOD (mg/L) } & \multicolumn{2}{c|}{ COD (mg/L) } \\
\cline { 2 - 9 } & $\begin{array}{c}\text { Dry } \\
\text { season }\end{array}$ & $\begin{array}{c}\text { Wet } \\
\text { season }\end{array}$ & $\begin{array}{c}\text { Dry } \\
\text { season }\end{array}$ & Wet season & $\begin{array}{c}\text { Dry } \\
\text { season }\end{array}$ & Wet season & $\begin{array}{c}\text { Dry } \\
\text { season }\end{array}$ & $\begin{array}{c}\text { Wet } \\
\text { season }\end{array}$ \\
\hline \multirow{2}{*}{ SS1 } & 6.67 & 6.48 & 2.16 & 9.18 & 2.23 & 2.81 & 61 & 72.33 \\
& \pm 0.42 & \pm 0.67 & \pm 0.087 & \pm 0.17 & \pm 0.10 & \pm 0.37 & \pm 2.65 & \pm 5.51 \\
\hline \multirow{2}{*}{ SS2 } & 8.67 & 6.66 & 2.51 & 8.97 & 2.80 & 3.1 & 61.67 & 77.43 \\
& \pm 0.21 & \pm 0.61 & \pm 0.11 & \pm 0.09 & \pm 0.04 & \pm 0.12 & \pm 2.08 & \pm 4.18 \\
\hline \multirow{2}{*}{ SS3 } & 8.96 & 6.63 & 2.34 & 7.54 & 2.79 & 2.98 & 60 & 77.3 \\
& \pm 0.03 & \pm 0.77 & \pm 0.148 & \pm 1.14 & \pm 0.076 & \pm 0.15 & \pm 2 & \pm 9.02 \\
\hline \multirow{2}{*}{ SS4 } & 8.65 & 6.59 & 2.05 & 7.83 & 2.26 & 2.72 & 68.13 & 73.27 \\
& \pm 0.92 & \pm 0.61 & \pm 0.09 & \pm 0.87 & \pm 0.06 & \pm 0.25 & \pm 1.70 & \pm 3.26 \\
\hline \multirow{2}{*}{ SS5 } & 9.2 & 7.59 & 1.58 & 2.7 & 3.12 & 3.91 & 71.5 & 80.63 \\
& \pm 0.16 & \pm 0.095 & \pm 0.12 & \pm 0.58 & \pm 0.07 & \pm 0.04 & \pm 1.10 & \pm 6.97 \\
\hline \multirow{2}{*}{ SS6 } & 8.8 & 7.32 & 2.76 & 7.92 & 2.85 & 3.02 & 71.67 & 83.1 \\
& \pm 0.27 & \pm 0.18 & \pm 0.08 & \pm 0.48 & \pm 0.01 & \pm 0.23 & \pm 1.53 & \pm 8.15 \\
\hline
\end{tabular}




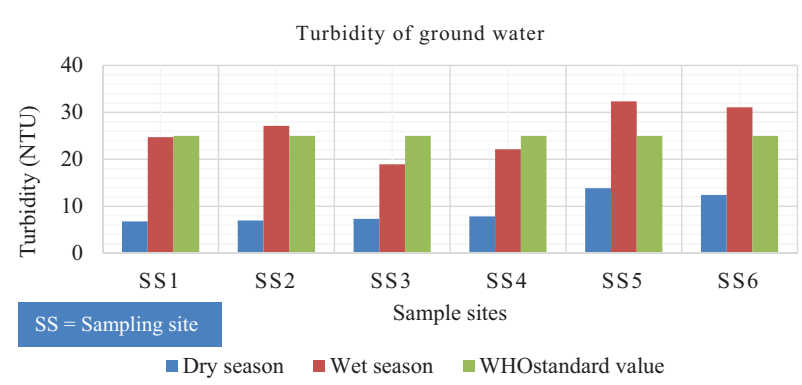

Figure 4. Seasonal variation in turbidity of groundwater quality in the study area

of the sample points from the waste disposal site. This higher value of turbidity in a wet season resembles the work of (Makwe \& Chup, 2013) who assesses the seasonal variation in Physico-chemical properties of groundwater around Karu abattoir. Figure 4 shows that, on the base of spatial variation in both dry and wet season the maximum values of turbidity were observed at $\mathrm{SS}_{5}$ and $\mathrm{SS}_{6}$ whereas the minimum value at $\mathrm{SS} 1$ for the dry season and at $\mathrm{SS}_{3}$ for the wet season. This was due to the location of those sample points $\left(\mathrm{SS}_{5}\right.$ and $\mathrm{SS}_{6}$ ) were below the waste disposal site which is susceptible for more agricultural runoff and discharged municipal waste flow freely and a number of people are using those sample points in common for their domestic purpose, as a result, particles will not get enough residence time for settling while $\mathrm{SS}_{1}$ and $\mathrm{SS}_{3}$ are located above the dump site which is expected the effect of waste disposal site is non-significant. Generally, the high turbidities constitute a health risk for the children consuming this water. High turbidity also indicates a higher amount of total suspended solids which might include microorganisms such as bacteria or parasites as well as an increase in the concentration of minerals (Oram, 2015). Watershed features, such as geology, chemical fertilizer and pesticide runoff from agricultural activities, urban development activities, topography, vegetation and precipitation events can all greatly influence raw water turbidity in the study area.

\subsubsection{Spatial and temporal variation in chemical characteristics of groundwater quality}

The result of spatial and temporal variation of groundwater chemical parameters measured in all six sampling

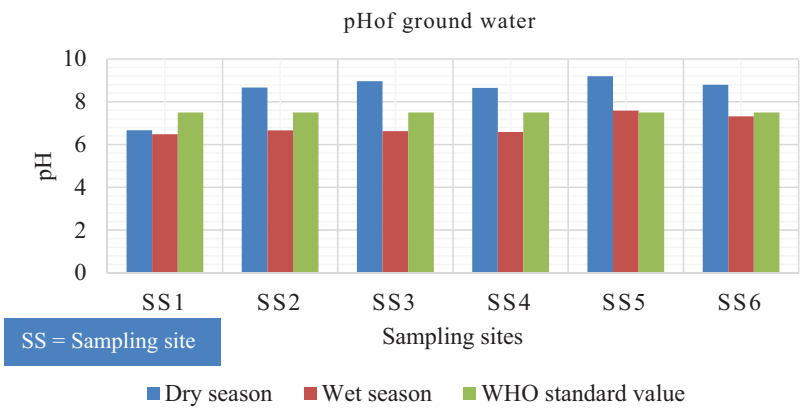

Figure 5. Seasonal variation in $\mathrm{pH}$ of groundwater quality in the study area points throughout the study time are presented in below table.

Groundwater $\mathrm{pH}$ : The measurement of $\mathrm{pH}$ is one of the most frequently used tests in water chemistry. The $\mathrm{pH}$ results for the groundwater samples of the study areas ranged from $6.67 \pm 0.42$ to $9.2 \pm 0.16$ with a mean value of $8.49 \pm 0.33$ for the dry season and ranged from $6.48 \pm 0.67$ to $7.59 \pm 0.095$ (Figure 5) with a mean value of $6.88 \pm 0.49$ for wet seasons. The analysis result of water samples shows the $\mathrm{pH}$ of groundwater was above the WHO allowable limit of 5.5-7.5 for drinking water for both wet and dry season (Figure 5, Table 2). This could be due to run off from the community (Humans contribute to elevated $\mathrm{pH}$ primarily in the form of nutrient runoff most commonly fertilizer). As from the Figure 5 below indicated at $\mathrm{SS}_{1}$ and $\mathrm{SS}_{5}$ registered the lowest and the highest $\mathrm{pH}$ values throughout the period of study respectively. In the base of seasonal variation, the mean value of $\mathrm{pH}$ in groundwater was lower in the wet season than in the dry season (Figure 5, Table 2) This may have been due to during wet season rainfall combines with carbon dioxide can influence the water toward acidity, lower temperature hence lower TDS values, adsorption processes and lower ion exchange capacity taking place (Bogan et al., 2009). The findings of lower value $\mathrm{pH}$ in a wet season during the study period was similar with the work of (Idoko \& Oklo, 2012) who investigates seasonal variation in Physico-chemical characteristics of rural groundwater of Benue state, Nigeria and found out lower value of $\mathrm{pH}$ during wet season. Therefore, carbon dioxide is the most common cause of acidity in water. Photosynthesis, respiration and decomposition all contribute to $\mathrm{pH}$ fluctuations due to their influences on $\mathrm{CO}_{2}$ levels. The $\mathrm{pH}$ values within the range of 5.5-7.5 were suitable for the normal range of irrigation (Kay, 2001). The $\mathrm{pH}$ of the Groundwater falls above FAO and WHO water quality guidelines for irrigation and use as raw public water supply in dry season (Figure 5, Table 2). According to (Kay, 2001) $\mathrm{pH}$ exceeds from 7.5 is not advisable for irrigation purpose. Generally, the acidity may have been due to high carbon dioxide concentrations from eutrophication processes of organic matter, adsorption of metal anions and presence of some non-metallic compounds such as fluorides in the groundwater sources. The low $\mathrm{pH}$ values which were common in the wet season are attributed to the anaerobic conditions that could lead to the production of acidic substances such as organic acids.

Dissolved oxygen: The findings of the study show that the values of dissolved oxygen were ranged between $2.05 \pm 0.09$ to $2.76 \pm 0.08 \mathrm{mg} / \mathrm{L}$ during dry season (Figure 6, Table 2) with the mean value of $2.24 \pm 0.102 \mathrm{mg} / \mathrm{L}$ where as in the wet season from $2.7 \pm 0.58$ to $9.18 \pm 0.17 \mathrm{mg} / \mathrm{L}$ with the mean value of $7.36 \pm 0.56 \mathrm{mg} / \mathrm{L}$ (Figure 6, Table 2). The recorded results (Figure 6) indicate that the amount of dissolved oxygen during wet season were higher than the value of dry season. This might have been due to temperature and rain fall. This was in line with the study of (Makwe \& Chup, 2013) who investigates the seasonal 
variations in physicochemical properties of groundwater around Karuabattoir. As recorded above the amount of temperature measured in a wet season was lower than dry season and then it has a tendency to hold high dissolved oxygen which leads dissolved oxygen to be higher in wet season. Besides to those in wet season oxygen is mixed in through rain, wave and wind as a result its value to be recorded at the sample point was increase as compared to dry season. Also, spatial variation among the six sample points in both dry and wet season was observed. Figure 6, and Table 2 shows that in dry season the minimum value was measured at sampling point 5 . This was due to sampling point 5 was the highest in depth from all. Then at the highest depth, air was not interacting more relatively and the water that is near the sediment will be depleted of oxygen. On the other hand, the maximum value of dissolved oxygen in dry season was measured at sampling point 6 (Figure 6, Table 2) which is typically spring water. Although spring waters are considered as ground water, they are simply absorbing oxygen from atmospheric air as a result sampling point 6 has higher value as compared to the other. Where as in the wet season the maximum value occurs at sampling point (Figure 6, Table 2) due to this sampling point is found far apart from the dump site in the upstream direction (above the dump site) and the minimum value at sampling point 5 similar to dry season. The oxidation of organic substances and reduced inorganic substances leads to lower oxygen content in groundwater. Generally, a high content of oxygen infiltration water enriches the groundwater with oxygen. Because of most groundwater recharge takes place in the wet season and lower solubility of oxygen in warm water than in cold water, higher contents of dissolved oxygen are measured in the wet season. However, in wet season the measured mean value of DO was above $\mathrm{WHO}$ water quality permissible limit of $5 \mathrm{mg} / \mathrm{L}$. On the account of this the statistical analysis of variance (ANOVA) result indicates that there was significant difference in mean DO concentration between and within seasons during the study period ( $\mathrm{p}$ $<0.05$ ). As dissolved oxygen levels in water drop below $5.0 \mathrm{mg} / \mathrm{L}$, aquatic life is put under stress. The lower the concentration, the greater the stress. Low dissolved oxygen (DO) primarily results from excessive algae growth caused by phosphate. As the algae die and decompose, the process consumes dissolved oxygen. This can result in insufficient amounts of dissolved oxygen available for aquatic life.

Biological oxygen demand: From the study, the amount of BOD for all samples during the dry season were ranged from $2.23 \pm 0.10$ to $3.12 \pm 0.07 \mathrm{mg} / \mathrm{L}$ with a mean value of $2.68 \pm 0.07 \mathrm{mg} / \mathrm{L}$ while during the wet season the value of BOD varies from $2.72 \pm 0.25$ to $3.91 \pm 0.04 \mathrm{mg} / \mathrm{L}$ with a mean value of $3.09 \pm 0.202 \mathrm{~m} / \mathrm{L}$ (Figure 7, Table 2). The findings of this study show that the mean value of the wet season was higher than the mean value of the dry season (Figure 7, Table 2). This might have been due to percolation and infiltrations of biodegradable organic matter and leaching of organic iron and or manganese

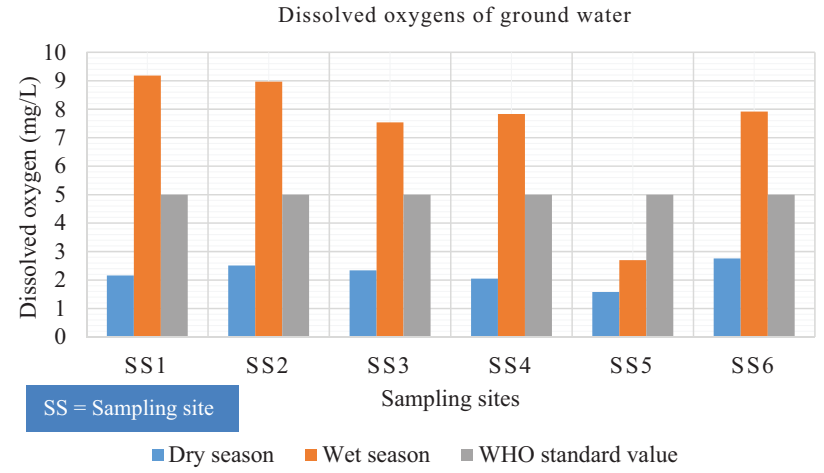

Figure 6. Seasonal variation in the dissolved oxygen of groundwater quality in the study area

into the aquifers because of the waste disposal site. The higher BOD observed in the rainy season implied that high demand for oxygen was made to support the life process (Clark, 1986) noted similar situations of high BOD and conclude that it was due to higher organic waste load experienced during the rainy season. (Odokuma \& Okpokwasili, 1993) also observed that BOD fluctuation between season may be attributed to additional organic matter introduced into groundwater as the result of runoff and soil erosion caused by continuous rainfall in the rain season. In the aspect of spatial variation, the maximum BOD value was recorded at sampling point 5 and sampling point 6 respectively for both dry and wet season (Figure 7, Table 2). This was due to the depth of boreholes and the locations of sample points from the waste disposal site (the pollutant source) since in the highest in-depth and downstream from the pollutant source mostly characterized by a deficiency of oxygen. Whereas the minimum values were obtained at sampling point 1 and sampling point 4 (Figure 7, Table 2) respectively for both dry and wet season due to both are located above the dumping site which is not rich with a significant amount of organic waste that comes from the source (disposal site). Generally, the BOD values of groundwater samples throughout the study period were below the EPA'S/WHO/guideline values of $5 \mathrm{mg} / \mathrm{l}$ (Figure 7, Table 2). This indicates that the water was moderately good interims of BOD for different household activities, because low BOD is an indicator of good quality water, while a high BOD indicates polluted

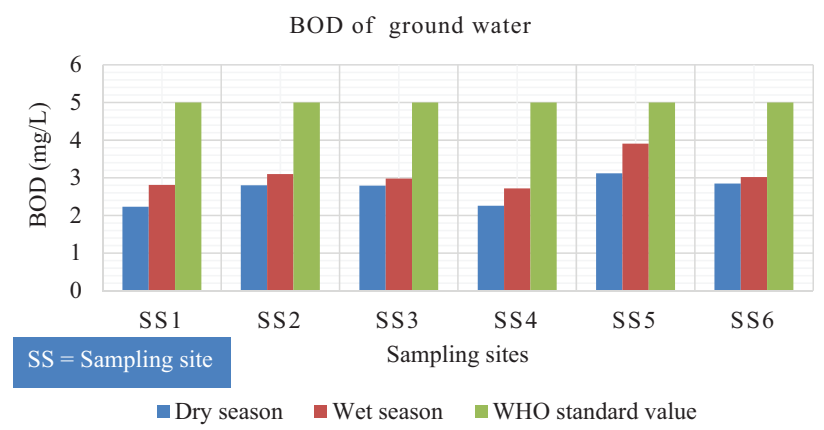

Figure 7. Seasonal variation in the BOD of groundwater quality in the study area 
water. From the ANOVA result, there was no possible significant variation between the sampling points as well as between the seasons that might lead the BOD beyond the limit of WHO. In water with a BOD level of above $5 \mathrm{mg} / \mathrm{L}$, the water is considered somewhat polluted because there is usually organic matter present and bacteria are decomposing this waste. The higher the BOD value, the greater the amount of organic matter or food available for oxygenconsuming bacteria. BOD values increase when nutrient loads and accumulation of plant decaying matters in sampling points increase.

Chemical oxygen demand: COD is an indicator of organic pollution, which is caused by the inflow of domestic waste, live stocks and industrial waste that contains an elevated level of organic pollutants (Maitera et al., 2010). The investigations of the study show that chemical oxygen demand in all the six groundwater samples ranged from $60 \pm 2$ to $71.67 \pm 1.53 \mathrm{mg} / \mathrm{L}$ during the dry season with a mean value of $65.67 \pm 1.84$ while in the wet season it ranged from $72.233 \pm 5.51$ to $83.1 \pm 8.15 \mathrm{mg} / \mathrm{L}$ with a mean value of $77.34 \pm 6.18 \mathrm{mg} / \mathrm{L}$ (Figure 8 , Table 2). From this (Figure 8 and Table 2) one can see that the values of both dry and wet season were below the $\mathrm{EPA} / \mathrm{WHO} /$ guideline permissible limit. This could probably be because most of the wastes that are being generated from the various communities (available at the dumpsite) are biodegradable or the observed pollutions of borehole water samples studied may not be due to chemical oxidation of pollutants present but due to aerobic degradations of organic matter present by microorganism in the water samples. Even though all values of this study conform to the standard limit the mean value of COD during the wet season was higher than the value of the dry season (Figure 8, Table 2). This might have been due to the effect of household chemical products such as detergents, soaps, shampoos, preservatives, dyes, and cleaners available in the dumpsite by the actions of rainfall. As a result of this, the prolong accumulation of seeped organic leachates in the aquifer can increase. The discoveries of the high value of COD in a wet season during the examination time frame of this research was comparable with the investigation of (Gadhia et al., 2012) who have done the examinations of seasonal variations in Physico-chemical characteristics of Tapi estuary in Hazira industrial area and discovered

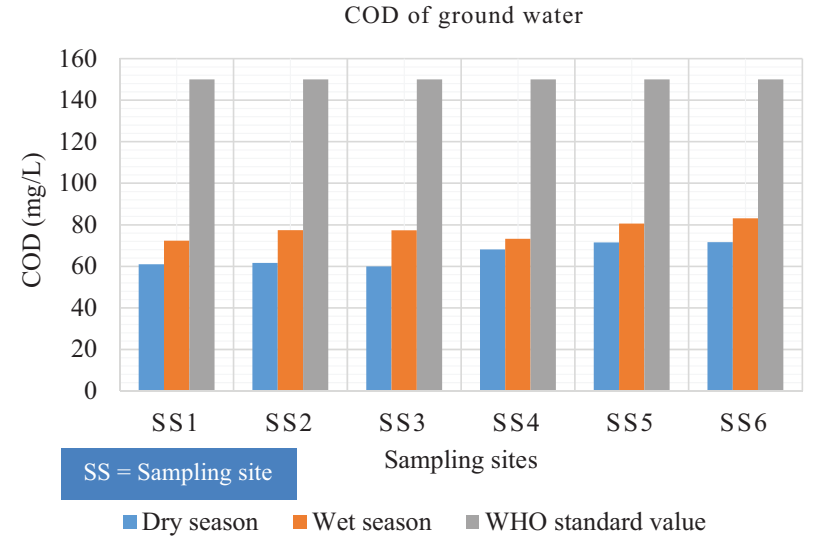

Figure 8 . Seasonal variation in the COD of groundwater quality in the study area

higher estimation of COD during the wet season than the dry season. In the base of spatial variation maximum and minimum values were recorded at sampling point 6 and sampling point 1 respectively for both dry and wet season (Figure 8, Table 2). When compared this finding with other studies a higher range of COD values than those in this study was obtained in the study that assessed the quality of boreholes located close to the dumpsite in Benin and south-south Nigeria. The COD range in this study show similar with COD range of $55-89 \mathrm{mg} / \mathrm{L}$ obtained in the assessment of water quality of borehole around selected landfills in Kanometroplis, north Nigeria, as well as some selected boreholes in Umiahia in Abia state, southeast Nigeria, in that they are below the recommended value set by WHO (Onwugara et al., 2013).

\subsubsection{Spatial and temporal variation of nutrients and micro biological parameters of groundwater quality}

The result of spatial and temporal variation of groundwater nutrients and microbiological parameters measured in all six sampling points throughout the study time are presented in Table 3.

Dynamics of nitrate in ground water: From the study, the concentrations of nitrate during dry season varied between $0.071 \pm 0.0011$ to $0.08 \pm 0.0021 \mathrm{mg} / \mathrm{L}$ with a mean value of $0.34 \pm 0.006 \mathrm{mg} / \mathrm{L}$ while in a wet season it ranged from $0.51 \pm 0.02$ to $0.94 \pm 0.056 \mathrm{mg} / \mathrm{L}$ with a mean value of

Table 3. Spatial and temporal variation in measured values of nutrients and micro biological parameters

\begin{tabular}{|c|c|c|c|c|c|c|}
\hline \multirow{2}{*}{$\begin{array}{c}\text { Sampling sites } \\
(\mathrm{SS})\end{array}$} & \multicolumn{2}{|c|}{$\mathrm{NO}_{3}{ }^{-}(\mathrm{mg} / \mathrm{L})$} & \multicolumn{2}{c|}{$\mathrm{PO}_{4}{ }^{3-}(\mathrm{mg} / \mathrm{L})$} & \multicolumn{2}{c|}{$\mathrm{TC}(\mathrm{CFU} / 100 \mathrm{ml})$} \\
\cline { 2 - 7 } & Dry season & Wet season & Dry season & Wet season & Dry season & Wet season \\
\hline SS1 & $0.071 \pm 0.0011$ & $0.53 \pm 0.056$ & $0.0058 \pm 0.003$ & $0.0018 \pm 0.001$ & $8.33 \pm 0.1 .53$ & $13 \pm 3$ \\
\hline SS2 & $0.72 \pm 0.023$ & $0.66 \pm 0.053$ & $0.0088 \pm 0.0029$ & $0.031 \pm 0.023$ & $6.33 \pm 1.53$ & $13.67 \pm 5.132$ \\
\hline SS3 & $0.09 \pm 0.003$ & $0.94 \pm 0.056$ & $0.048 \pm 0.0023$ & $0.0072 \pm 0.005$ & $7.33 \pm 3.51$ & $18.33 \pm 4.51$ \\
\hline SS4 & $0.73 \pm 0.01$ & $0.51 \pm 0.02$ & $0.039 \pm 0.003$ & $0.05 \pm 0.0075$ & $5 \pm 1$ & $16 \pm 1$ \\
\hline SS5 & $0.073 \pm 0.0021$ & $0.52 \pm 0.16$ & $0.064 \pm 0.0042$ & $0.264 \pm 0.0 .34$ & $11.67 \pm 2.52$ & $23 \pm 6$ \\
\hline SS6 & $0.08 \pm 0.0021$ & $0.55 \pm 0.06$ & $0.098 \pm 0.001$ & $0.262 \pm 0.87$ & $9 \pm 2$ & $20 \pm 4.583$ \\
\hline
\end{tabular}


$0.62 \pm 0.07 \mathrm{mg} / \mathrm{L}$ (Figure 9, Table 3). The result of Figure 9 shows that all values of the dry and wet season were extremely below the WHO standard value of $50 \mathrm{mg} / \mathrm{L}$ for groundwater. This could probably be due to the absence of DO significantly in the wastewater; a smaller amount of nitrate is produced from ammonia as well as decomposition of food wastes and other sources of protein. Mostly factors affecting the occurrence of nitrate in groundwater boreholes are subsurface clay lenses and land use practice. The disclosures/findings/ of low values of nitrate (below WHO standard) during the examination time frame was similar with the work of (Akale et al., 2018) who have assessed nitrate in wells and springs in the north-central Ethiopian high lands and found value which is less than WHO standard limit throughout the study period. Even though all values were below the permissible limit the mean concentrations of nitrate obtained during wet season were higher than the value of dry season (Figure 9, Table 3). The disclosures of the high value of nitrate in a wet season during the study period were similar to the research of (Akale et al., 2017) who investigates groundwater quality in an upland agricultural watershed in the sub-humid Ethiopian highlands and found out the higher value of nitrate during the wet season than the dry season. This might have been due to high nitrate concentration in the wet season suggested that increased flush of nitrate causing components (mixed source such as decaying plant or animal material, agricultural fertilizers, manure, compost, human or animal waste, and domestic sewage) derived from waste disposal site and the areas around during storm event resulted in nitrate concentration or the increased nitrate level was due to freshwater inflow and terrestrial run-off during the wet season (Karuppasamy \& Perumal, 2000). Another possible way of nitrates entry is through oxidation of ammonia form of nitrogen to nitrite formation (Rajasegar, 2003). Generally, during rainy season groundwater is recharged through precipitation via percolation leading to a general rise in the level of the water. This makes them highly susceptible to pollution and runoff activities as elements in soils and rocks are easily released into the water. The main source of nitrate in these groundwater samples could be attributed use of chemical fertilizers on farms, effluent discharges and runoff from animal feedlots have been identified as one of the main causes of nitrate in groundwater. Besides, improper disposal of human and animal wastes on open land results in leaching of residual nitrate thereby causing high nitrate concentration in groundwater in the wet season. In most case uses of chemical fertilizers; improper disposal of human and animal wastes and effect of seasons are fundamental factors for sources of nitrogen-containing compounds that are converted to nitrate in the soil. On the other hand, the low mean value was recorded during the dry season due to less freshwater inflow and high salinity (Krishnamurthy \& Mani, 1989). In the aspect of spatial variation, the maximum value was obtained at sampling point 4 and with a minimum value at sampling point 1 during the dry season while in the wet season the

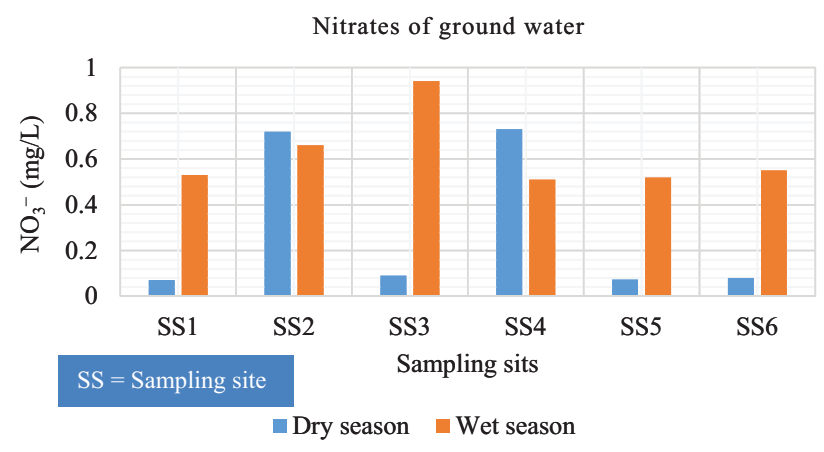

Figure 9. Seasonal variation in the nitrate of groundwater quality in the study area

maximum value occurs at sampling point 3 with a minimum value at sampling point1 (Figure 9). The reason for the values to be maximum might have been due to plant decaying, manure, compost, and runoff since sampling point 3 and sampling point 4 borehole samples are found particularly at grazing land and gardens while for the minimum the reverse is true. From the ANOVA result, there was no possible significant variation between the sampling points as well as between the seasons that might lead the concentration of nitrate above the limit of WHO.

Dynamics of phosphate in ground water: The concentration of phosphate in the groundwater samples ranged from $0.0088 \pm 0.0029$ to $0.098 \pm 0.001 \mathrm{mg} / \mathrm{L}$ in the dry season and $0.002 \pm 0.001$ to $0.264 \pm 0.0 .34 \mathrm{mg} / \mathrm{L}$ in the rainy season (Figure 10, Table 3). The findings of the study show that higher levels of phosphate concentrations were however registered during the wet seasons compared to dry seasons in all the groundwater samples (Figure 10, Table 3). This difference can be explained in terms of increased moisture in the ground of waste disposal site which contains human wastes, medicated shampoos, food waste and cosmetics that can leach the phosphate into groundwater. Generally, the value of phosphate during the rainy season can increase due to the possible input of phosphates from the external environment, improper disposal of solid wastes and runoff due to excessive use of chemical fertilizers into the water and natural decomposition of rocks and minerals that contain phosphates. Phosphates are usually highly adsorbed into the soil and can be transported into the catchments and the recipient water

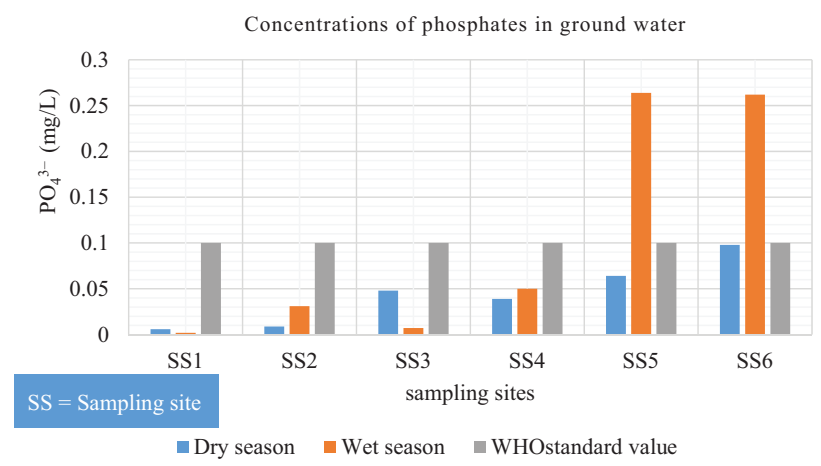

Figure 10. Seasonal variation in the phosphate of groundwater quality in the study area 
bodies by the actions of rain and then accounted for the high phosphate concentration in local water bodies. The minimum value of phosphate was registered during the dry season, this might have been due to the low solubility of native phosphate minerals and the ability of soils to retain phosphate. This is in line with the findings of (Gadhia et al., 2012) who investigates seasonal variations in Physico-chemical characteristics of Tapi estuary in the Hazira industrial area and found out a higher value of phosphate during the wet season than dry. From the point of spatial variation, the highest concentrations of phosphate were recorded at sampling point 5 followed by sampling point 6 during the rainy season with a minimum value at sampling point 1 while in the dry season the highest level was at sampling point 6 with a minimum value at sampling point 2 (Figure 10, Table 3). This was due to the locations of boreholes from the selected waste disposal site. From below obtained result (Figure 10) except sampling point 5 and sampling point 6 the concentration of $\mathrm{PO}_{4}{ }^{3-}$ in both dry and wet seasons were below WHO standards limit $\left(\mathrm{PO}_{4}{ }^{3-}=0.1 \mathrm{mg} / \mathrm{L}\right)$. On account of this, the statistical analysis of variance (ANOVA) results indicates that there was no significant difference in mean phosphate concentration between and within sampling points as well as seasons during the study period $(\mathrm{p}<0.05)$.

Total coliform: The results of the bacteriological analysis of borehole water samples indicate that the amount of total coliform during the dry season was ranged from $5 \pm 1$ to $11.67 \pm 2.52 \mathrm{CFU} / 100 \mathrm{ml}$ with a mean value of $7.9 \pm 2.01 \mathrm{CFU} / 100 \mathrm{ml}$ whereas in a wet season the total coliform fluctuated from $13 \pm 3$ to $23 \pm 6 \mathrm{CFU} / 100 \mathrm{ml}$ with a mean value of $17.3 \pm 4.04 \mathrm{CFU} / 100 \mathrm{ml}$ (Figure 11, Table 3). From the result, one can see that the bacterial colony counts were all above the WHO guideline limit of $0 \mathrm{CFU} / 100 \mathrm{ml}$ for drinking purposes. Therefore, groundwater samples were contaminated with total coliform. This must be due to wastes particularly human wastes which are transported from Bahir Dar city and discharged directly to the open land (at the open waste disposal site). It can, therefore, be inferred that the boreholes were mainly polluted by the drains emanating from the waste site that empty their content directly into the open land. The measured mean value of total coliform during the wet season was higher than that of the dry season. This could be due to the discharged human wastes or fecal matters are flushed/washed/ away by the actions of rainfall from its source to the different water bodies. Then during its flow, it joins surface waters and open boreholes besides leaching into groundwater through percolation and infiltration. The transport of bare soil contaminated with farces by the wind/rain/ into open bores as well as surface runoff could also have accounted for the high bacterial load during the wet season as compared to the dry season. Sample points that are nearest to the disposal site in the downstream like sampling point 5 and sampling point 6 were more affected by the total coliform. Un expectedly sample points which are located above the dumpsite were polluted with total coliform. This might have been due to

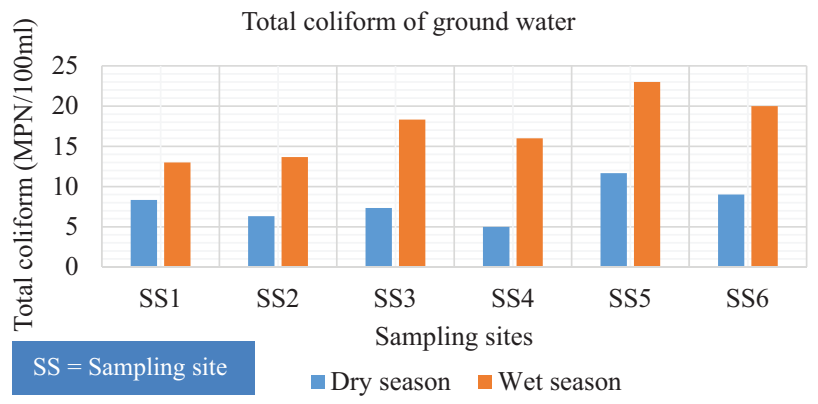

Figure 11. Seasonal variation in total coliform of groundwater quality in the study area

faeces and other wastes from anthropogenic sources (open field defecation along the boreholes by humans and other animals that graze along with the groundwater samples) located in bushes close to boreholes. This was eventually washed by rainwater as runoff towards groundwater samples and then leaked into groundwater besides to mix with the open boreholes and spring water via surface flow. The maximum values among the six groundwater samples were found at sampling point 5 sampling point 6 , sampling point 1 and sampling point 3 with a minimum at sampling point 4 during the dry season while in a wet season the maximum values were obtained at sampling point 5 , sampling point 6 , sampling point 3 and sampling point 4 with a minimum at sampling point 1 . The temporal mean value of total coliform in the water at the six sampling points of the study area during the dry and wet season were shown in Figure 11.

\subsection{Assessing/Evaluating/ groundwater Quality of Chilanchil Abay watershed through Water Quality Index (CCMEWQI)}

In this study, the CCME Water Quality Index was applied and tested for the Chilanchil Abay Watershed quality. The index ranges from 0 to 100 and depending on the value; the water quality is characterized as excellent, good, fair, marginal and poor. The CCME WQI was calculated using the method described by CCME 2001 guidelines (Eqs (1), (2), (3), (4), (5), (6) and (7). The results obtained from the application of CCME WQI concerning nutrients, heavy metals, and Physico-chemical characteristics were presented in Table 4 and Figure 12.

Table 4. variation of WQI of Chilanchil Abay watershed with different sampling points

\begin{tabular}{|l|l|l|}
\hline \multicolumn{1}{|c|}{ Sampling points } & \multicolumn{1}{|c|}{ level } & \multicolumn{1}{c|}{ Status } \\
\hline $\mathrm{SS}_{1}$ & 46.2 & Marginal \\
\hline $\mathrm{SS}_{2}$ & 45.53 & Marginal \\
\hline $\mathrm{SS}_{3}$ & 45.52 & Marginal \\
\hline $\mathrm{SS}_{4}$ & 45.53 & Marginal \\
\hline $\mathrm{SS}_{5}$ & 42. & Poor \\
\hline $\mathrm{SS}_{6}$ & 42.2 & Poor \\
\hline
\end{tabular}




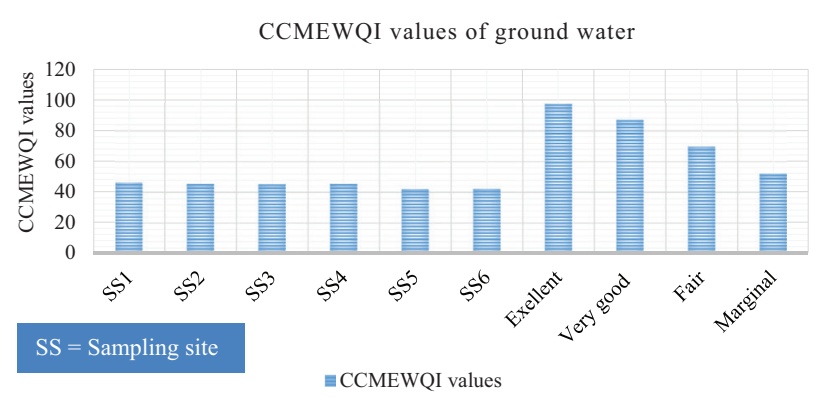

Figure 12. variations of water quality index in the study area at different groundwater sample sites

Analysis in Chilanchil Abay watershed Table 4 above and Figure 12 below shows the variation of WQI with CCME standard level to evaluate the status of existing groundwater quality in the study area. The calculated results obtained from all sampling points of groundwater were showing four sample points as marginal and two sample points as poor for 30th March 2019 to 20th August 2019. All the marginal status sample points are found in the upstream of the waste disposal site. This indicates that Water quality is frequently endangered or deteriorated; conditions often deviate from natural or desirable levels. This could be resulted due to decaying of plants and animals, agricultural fertilizers and open defection activities. While the remaining two poor status sample points were found in the downstream of the waste disposal site. This indicates that the water quality of these sampling points is always endangered or deteriorated; conditions usually deviate from natural or desirable levels. Considering all sample sites, $\mathrm{SS}_{5}$ and $\mathrm{SS}_{6}$ have shown the worst quality in the context of CCMEWQI. The reasons may include the migrations of leachate in downstream from the dumpsite towards those two sample points.

\section{Conclusions}

The temporal and spatial variations of groundwater quality of Chilanchil Abay watershed was assessed following WHO quality parameters standards and Canadian water quality index. The analysis of physicochemical and concentrations of nutrients recorded values, show that $\mathrm{BOD}, \mathrm{COD}$, and $\mathrm{NO}_{3}{ }^{-}$were within the acceptable limit for groundwater quality during the study period while the remaining water quality characteristics fluctuated with the seasons. The total coliform counts detected were above the permissible limits for drinking water in all sample points. According to the Canadian water quality index (CCMEWQI), the water quality of Chilanchil Abay watershed was categorized under poor and marginal status.

From the findings of the study, it is assured that sample points downstream the dumpsite were more affected than the sample points of upstream.

Data suggested the importance of greater attention for household contamination, environmental sanitation control and awareness about water contamination since the open waste disposal site and practice of open defecation have actually impacted the watershed of the study area.

\section{Conflict of interest}

The Authors declare that there is no conflict of interest regarding the publications of this paper.

\section{Acknowledgements}

The authors would like to thank Bahir Dar University, Bahir Dar Institute of Technology for technical and financial supports of this project.

\section{Reference}

Afolayan, O., Ogundele, F., \& Odewumi, S. (2012). Spatial variation in landfills leachate solution in urbanized area of Lagos State, Nigeria. American International Journal of Contemporary Research, 2(8), 178-184. http://www.aijcrnet.com/journals/Vol_2_No_8_August_2012/17.pdf

Akale, A. T., Dagnew, D. C., Giri, S., Belete, M. A., Tilahun, S. A., Mekuria, W., \& Steenhuis, T. S. (2017). Groundwater quality in an upland agricultural watershed in the sub-humid Ethiopian highlands. Journal of Water Resource and Protection, 9(10), 1199. https://doi.org/10.4236/jwarp.2017.910078

Akale, A., Moges, M., Dagnew, D., Tilahun, S., \& Steenhuis, T. (2018). Assessment of nitrate in wells and springs in the North Central Ethiopian Highlands. Water, 10(4), 476. https://doi.org/10.3390/w10040476

Bogan, R. A., Ohde, S., Arakaki, T., Mori, I., \& McLeod, C. W. (2009). Changes in rainwater $\mathrm{pH}$ associated with increasing atmospheric carbon dioxide after the industrial revolution. Water, Air, and Soil Pollution, 196(1-4), 263-271. https://doi.org/10.1007/s11270-008-9774-0

Clark, R. B. (1986). Marine pollution ( $3^{\text {rd }}$ ed.). Oxford Science Press Publication, Calendon. B.

Clesceri, L., Greenberg, A., \& Eaton, A. (1998). Standard methods for the examination of water and wastewater (20 ${ }^{\text {th }}$ ed.). American Public Health Association, Washington, DC. http://srjcstaff.santarosa.edu/ oraola/Assets/APHA_SM_20.pdf

Gadhia, M., Surana, R., \& Ansari, E. (2012). Seasonal variations in physico-chemical characterstics of Tapi estuary in Hazira industrial area. Our Nature, 10(1), 249-257. https://doi.org/10.3126/on.v10i1.7811

Hamad, O. H. M. (2018). Occupational and environmental hazards among workers in petroleum stations, Khartoum State, Sudan (2013-2015). University of Gezira. http://repo.uofg.edu.sd/handle/123456789/3483

Idoko, M., \& Oklo, A. (2012). Seasonal variation in physicochemical characteristics of rural groundwater of Benue State, Nigeria. Journal of Asian Scientific Research, 2(10), 574-586. https://ideas.repec.org/a/asi/joasrj/2012p574-586.html

Karuppasamy, P., \& Perumal, P. (2000). Biodiversity of zooplankton at Pichavaram mangroves, South India. Advances in the Biosciences, 19(2), 23-32. https://www.sciencebase.gov/cata$\log /$ item/505772cee4b01ad7e027c1d2

Kay, M. (2001). Smallholder irrigation technology: Prospects for sub-Saharan Africa. Food \& Agriculture Organization of the United Nations. http://www.fao.org/publications/card/en/c/ f391cd0a-8d84-5d6e-8d30-4de028cad7ae/

Khan, A. A., Paterson, R., \& Khan, H. (2004). Modification and application of the Canadian Council of Ministers of the Environment Water Quality Index (CCME WQI) for the communication of drinking water quality data in Newfoundland and Labrador. Water Quality Research Journal, 39(3), 285-293. https://doi.org/10.2166/wqri.2004.039 
Krishnamurthy, K., \& Mani, P. (1989). Variation of phytoplankton in a tropical estuary (Vellar estuary, Bay of Bengal, India). Internationale Revue der gesamten Hydrobiologie und Hydrographie, 74(1), 109-115.

https://doi.org/10.1002/iroh.19890740109

Love, J., \& Luchsinger, V. (2014). Sustainability and water resources. Journal of Sustainability and Green Business, 2, 1-12. https://www.aabri.com/manuscripts/121354.pdf

Maitera, O., Ogugbuaja, V., \& Barminas, J. (2010). An assessment of the organic pollution indicator levels of River Benue in Adamawa State, Nigeria. Journal of Environmental Chemistry and Ecotoxicology, 2(7), 110-116. https://academicjournals. org/article/article1379512159_Maitera\%20et\%20al.pdf

Makwe, E., \& Chup, C. (2013). Seasonal variation in physicochemical properties of groundwater around Karu abattoir. Ethiopian Journal of Environmental Studies and Management, 6(5), 489-497. https://doi.org/10.4314/ejesm.v6i5.6

Markandya, A. (2006). Water quality issues in developing countries. In R. López \& M. A. Toman (Eds.), Economic development and environmental sustainability: New policy options (pp. 307-344). https://doi.org/10.1093/0199298009.003.0011

Nathanson, J. (2015). Solid-waste management. Encyclopaedia Britannica.
Nsengimana, H., Bigirimana, B., Suwa, M., Mukubwa, A., Debruyn, W., \& Kalisa, N. (2012). Assessment of heavy metals $(\mathrm{Pb}, \mathrm{Cu}, \mathrm{Cr}, \mathrm{Cd}$ and $\mathrm{Fe})$ in the groundwater wells in the vicinity of Nyanza Municipal Solid waste in Kigali City-Rwanda. Rwanda Journal, 25(1), 3-21. https://doi.org/10.4314/rj.v25i1.1

Odokuma, L. O., \& Okpokwasili, G. C. (1993). Seasonal ecology of hydrocarbon-utilizing microbes in the surface waters of a river. Environmental Monitoring and Assessment, 27(3), 175-191. https://doi.org/10.1007/BF00548364

Onwugara, N., Ajiwe, V., \& Nnabuenyi, H. (2013). Physicochemical studies of water from selected boreholes in Umuahia north Local Government Area of in Abia State, Nigeria. International Journal of Pure \& Applied Bioscience, 1(3), 3444. http://www.ijpab.com/form/2013\%20Volume\%201,\%20 issue\%203/IJPAB-2013-1-3-34-44.pdf

Oram, B. (2015). Stream water quality - Importance of total suspended solids/turbidity. https://www.water-research.net/index. $\mathrm{php} /$ stream-water-quality-importance-of-total-suspendedsolids-turbidity

Rajasegar, M. (2003). Physico-chemical characteristics of the Vellar estuary in relation to shrimp farming. Journal of Environmental Biology, 24(1), 95-101.

https://pubmed.ncbi.nlm.nih.gov/12974418/ 